\title{
Raynaud-szindrómás betegek életminőségének jellemzői
}

\author{
Fábián Balázs $^{1}$ - Csiki Zoltán dr. ${ }^{2 *}$ - Bugán Antal dr. ${ }^{1 *}$ \\ ${ }^{1}$ Debreceni Egyetem, Népegészségügyi Kar, Klinikai és Egészségpszichológiai Tanszék, \\ Magatartástudományi Intézet, Debrecen \\ ${ }^{2}$ Debreceni Egyetem, Általános Orvostudományi Kar, Belgyógyászati Klinika, Debrecen
}

\begin{abstract}
Bevezetés: A Raynaud-szindróma az erek epizodikus spasmusával és ischaemiájával járó kórkép, amely az érintett területek fájdalmát, zsibbadását és hidegségét okozza. A krónikusan jelentkező, komoly szubjektív panaszok ellenére az eddigi kutatásokban a kórkép életminőség szempontú vizsgálata eddig kevés hangsúlyt kapott.

Célkitüzés: A szerzők célul tüzték ki annak vizsgálatát, hogy a betegség fennállása hogyan hat az életminőségre.

Módszer: Félig strukturált interjúkat készítettünk és elemeztünk ki 28, Raynaud-szindrómával diagnosztizált beteg bevonásával.

Eredmények: Az életminőség csaknem összes területe érintett. A betegség szomatikus tünetei jelentős szenvedést okoznak, a végtagok funkcióromlásával járnak, gyakori megelőző intézkedéseket igényelnek, továbbá hatással vannak a munkavégzésre, közlekedésre és az alvásra is. Az érzelmi és a kognitív terheltség és a személyközi kapcsolatok negatív változása is kimutatható volt.

Következtetés: A vizsgálat megmutatta, hogy a betegség jelentős teherként jelenik meg a mindennapi élet számos területén. A krónikus betegség okozta pszichés megterhelés és életminőség-romlás miatt az orvosi ellátás mellett a pszichológiai ellátási forma is indokoltnak tekinthető.
\end{abstract}

Orv Hetil. 2018; 159(16): 636-641.

Kulcsszavak: Raynaud-szindróma, életminőség, stressz

\section{Quality of life of patients with Raynaud's disease}

Introduction: Raynaud's disease is characterized by episodic vasospastic attacks and digital ischemia usually followed by pain, numbness and cold. Despite the severity of the symptoms, the investigation of the quality of life in this disease received less attention yet.

Aim: The aim of the study was to examine how the disease affects the patients' quality of life. Method: Semi-structured interviews were made with 28 patients diagnosed with Raynaud's disease.

Results: Almost every domain of quality of life is negatively affected. The somatic symptoms cause significant suffering, they are accompanied by loss of functionality; frequent preventive actions are needed; furthermore they affect job performance, commuting and sleep quality. Emotional and cognitive burdens and negative changes in interpersonal relationships were found.

Conclusion: The findings of this study show that the disease is present as significant hardship in every aspect of daily life. Because of the decrease in the quality of life and the psychological burdens caused by this chronic disease, not only the basic medical care, but psychological treatment is also indicated.

Keywords: Raynaud's disease, quality of life, stress

Fábián B, Csiki Z, Bugán A. [Quality of life of patients with Raynaud’s disease]. Orv Hetil. 2018; 159(16): 636-641.

(Beérkezett: 2017. december 27.; elfogadva: 2018. február 10.)

*A szerzők utolsó szerzőként egyenlő mértékben járultak hozzá a kézirat összeállításához. 
A Raynaud-jelenség olyan mikrocirkulációs zavar, melyben a distalis kis erek/kapillárisok reverzibilis vasospasmusa figyelhető meg epizodikus jelleggel. Ezek az epizódok, vagy rohamok, jellemzően a kézujjak színének változásával járnak együtt, és fóbb kiváltó okuk a hideg környezet, illetve a pszichés stressz $[1,2]$. A kórképet először Maurice Raynaud írta le a XIX. században a betegein végzett megfigyelései alapján [3]. Lewis csaknem 70 év múlva tett javaslata nyomán a jelenséget az ujjakban keletkező érszúkületként értelmezzük [4]. A jelenség patofiziológiája ma még nem teljesen tisztázott, az erek funkcionális (a szekunder formákban strukturális) eltéréseként, csökkent értágulatra és megnövekedett érgörcsre való hajlamaként kezeljük [5]. A Raynaud-szindróma gyakorisága átlagosan $3-5 \%$ közé tehető $[3,6,7]$, míg más felmérések magasabb, 5-10\%-os előfordulási arányról számolnak be [8]. A jelenség szignifikánsan gyakoribb a nők körében [8] és a hidegebb éghajlatú országokban [9].

Klinikailag a Raynaud-szindrómának két típusát különböztetjük meg: az elsődleges (primer) és másodlagos (szekunder) formát. Ez elsődleges Raynaud-szindróma esetén a jelenség hátterében más betegség mint potenciális oki tényező nem található; míg a szekunder formában az érfal strukturális károsodása és a következményes klinikai tünetek egy másik kórkép, leggyakrabban reumatológiai, illetve szisztémás autoimmun betegségek következményeként fejlődnek ki [6]. Habár primer formában a funkcionális zavar etiológiai háttere nem tisztázott, egyes kutatások alapján a Helicobacter pylori kóroktani szerepe felmerülhet [10], illetve bizonyos gyógyszerek is kiválthatják és súlyosbíthatják a jellegzetes klinikai képet $[6,11]$. Mivel a Raynaud-szindróma tünetei gyakran megelőzik a háttérben álló alapbetegség egyéb tüneteit, a betegek folyamatos nyomon követése elengedhetetlen a helytálló diagnózis (primer/szekunder forma) és az esetleges alapbetegség megfelelő terápiájának időben való elindítása céljából [12]. Szekunder Raynaud-szindrómában a leggyakoribb alapbetegségek között említendő a szisztémás sclerosis [13, 14], a szisztémás lupus erythematosus [15] és a Sjögren-szindróma [16]. A betegek rendszeres követése során immunszerológiai vizsgálatok nyújthatnak támpontot, illetve kapillármikroszkóppal végzett vizsgálatok segítségével fedhetők fel a körömágy kis kapillárisainak morfológiai eltérései, amelyek előre jelezhetik a betegség progresszióját [17].

Az esetleges alapbetegség megfelelő terápiája mellett a Raynaud-szindróma három, egymás után következő lépésben kezelhető a súlyosságától függően: nem gyógyszeres kezelés, gyógyszeres kezelés és mütéti beavatkozás. A nem gyógyszeres kezelést fóleg az életmóddal kapcsolatos változtatások jelentik. Ennek keretében a dohányzásról való leszokás, a hidegnek való kitettség kerülése, vastagabb ruházat viselése, illetve a pszichés stressz kerülése javasolt a betegeknek [18, 19]. Megemlítendő az erőteljesen rezgő munkaeszközök használatának kerülése is. A szén- és ércbányászok [20], valamint a föld alatti vasutat építő keszonvájárok [21] esetén is figyelemre méltóan nagy gyakorisággal diagnosztizáltak Raynaud-szindrómát. A gyógyszeres kezelés tekintetében a kalciumcsatorna-blokkolók a legelterjedtebbek, mivel korábbi kutatások eredményei alapján alkalmazásuk sikeresen tudta csökkenteni a rohamok számát [22, 23]. Végső esetben szóba jöhet még a mütéti beavatkozás is, de ez csak a betegség tüneteinek kifejezetten súlyos jelenléte esetén és a gyógyszeres kezelések teljes hatástalansága mellett lehet indokolt $[1,2]$.

A megelőző jelleggel javasolt életmód-változtatás, mint a kesztyű folyamatos viselése, számos esetben nem elégséges a panaszok csökkentéséhez, vagy nem egyeztethető össze az egyén mindennapi tevékenységeivel, munkájával. Ezen túl, a kalciumcsatorna-blokkolók mint elsődlegesen választandó szerek számos nehezen tolerálható mellékhatással, úgymint szédüléssel vagy fejfájással járnak [24, 25]. Ezért a Raynaud-szindrómában szenvedők életminősége a betegség tünetein túlmenően a megelőző kényszerintézkedések és a gyógyszeres kezelés mellékhatásai miatt is jelentősen romolhat. Eddig meglehetősen kevés vizsgálat készült a Raynaud-szindrómában szenvedők életminőségével kapcsolatban, azonban az eredmények alapján a betegek életminősége egyértelmüen alacsonyabbnak tekinthető [26-28]. A Hughes és kollégái által készített vizsgálat eredménye szerint a legtöbb beteg úgy vélte, hogy az életminőségük valószínúleg sokkal jobb lenne, ha nem lenne a betegségük. A betegek nehezen tudták megjósolni a tünetek kiújulásának várható idejét, amely az állandó veszélyérzet miatt stressznövelő hatású. A betegek csupán fele volt képes a roham várható súlyosságát nagyon jól vagy jól megjósolni. Azt is kimutatták, hogy a betegek több mint $60 \%$-a csak rossz vagy nagyon rossz hatékonysággal volt képes a rohamokat bármilyen módon megelőzni. A betegek több mint $80 \%$-a szedett valamilyen gyógyszert a betegségére, viszont a gyógyszert szedő betegek mindössze 16\%-a vélte hatásosnak a gyógyszeres kezelést [29].

Annak vizsgálata által, hogy a panaszok hogyan rontják a betegek életminőségét, lehetőségünk nyílhat hatékonyabb kezelési módszerek vagy módszerkombinációk kialakítására. Ezért kutatómunkánk fó célkitűzése annak tanulmányozása volt, hogy a Raynaud-szindrómában szenvedők életére milyen hatással van a betegség. Mivel esetükben még nem áll rendelkezésre semmilyen specifikus mérőeszköz, olyan kvalitatív vizsgálat végzése mellett döntöttünk, amely várhatóan hiánypótló ismeretekkel fog szolgálni a betegségre specifikus életminőséget rontó jellemzőkról és folyamatokról.

\section{Módszer}

A Raynaud-szindrómával összefüggő életminőség-csökkenés vizsgálata céljából félig strukturált interjúkat készítettünk. A félig strukturált interjúforma jellemzője, a strukturált változattal szemben, a gondolatok és asszociációk spontánabb áramlása, amely teret enged a válasz- 
adónak arra, hogy véleményét kifejtse, s érzéseinek is hangot adjon. Így a válaszadók a vizsgálandó témakörök fókuszának megtartása mellett szabadon ki tudják emelni legfontosabb élményeiket és viszonyulásukat az adott kérdésben. Interjúkérdéseink megalkotásakor, a kórkép általános jellemzőin túl, az életminőség általános fö öszszetevői $[30,31]$ képezték az alapot. Ezen túlmenően a Raynaud-szindrómával gyakran társuló, illetve annak hátterében álló betegségek (például sclerosis multiplex, szisztémás lupus erythematosus, spondylitis ankylopoetica) specifikus életminőségét mérő kérdőívek [32-34] tartalmi köreit is figyelembe vettük abból a célból, hogy lehetőségünk legyen az életminőség legrelevánsabb területeire vonatkozó kérdéseket alkotni. Ugyanakkor a kérdések kialakításakor igyekeztünk azokat úgy megfogalmazni, hogy előzetes koncepciónk és ismereteink lehetőséget adjanak a betegséggel kapcsolatos minél változatosabb vélekedések megjelenítésére az interjú során. A kérdések a panaszok jellemzőire, javulásuk-rosszabbodásuk körülményeire, a mindennapi élet során korlátozó szerepükre (munkavégzés, közlekedés, szociális élet és intim kapcsolatok), illetve a panaszok csökkentésére tett kísérleti módszerekre kérdeztek rá. A jegyzőkönyvszerüen rögzített interjúk átlagosan 15 percet vettek igénybe, és 12 kérdést tartalmaztak. A vizsgálatba bevont, szakrendelésen megjelent betegek a Raynaudszindrómás panaszaik kezelésére pentoxifillin- és guaifenezintartalmú infúziós terápiában részesülnek 3-6 havonta. A kérdések az alábbiak voltak: „1. Melyek a fó panaszai?”; „2. A mindennapjai során mikor és hogyan korlátozzák Önt a panaszai?”; „3. Milyen helyzetekben szokta tapasztalni a panaszait?”; „4. A betegsége mivel terheli meg az egészségesekhez képest?”; „5. Hogyan szokta megpróbálni megelőzni a tüneteket?”; „6. Mit csinál, amikor a tünetei megjelennek?”; „7. Mióta van ez a betegsége? Akkor történtek-e jelentős változások az életében?”; „8. Mit gondol Ön a betegségének okáról?”; „9. Stressz hatására jelentkeznek tünetei?”; „10. Milyen érzéseket váltanak ki Önben a tünetek?”; „11. Vannak-e visszatérő gondolatai a betegségével kapcsolatban?”; „12. Mi a foglalkozása? Tartósan dolgozott-e hidegben?" A kezelés hatásaira nem vonatkozott kérdés, mivel a tanulmány keretében nem volt célunk a gyógyszeres kezelések által kifejtett hatás vizsgálata. Interjúalanyaink (n = 28; 18 nö, 10 férfi; 19-70 év közöttiek, átlagéletkoruk 53,5 év) azon betegek közül kerültek ki, akik a Debreceni Egyetem Általános Klinikai Központja Belgyógyászati Klinikájának Raynaud-szindróma-szakrendelésén részesülnek gondozásban, és a személyes megkeresés után vállalták a kutatásunkban való részvételt. A vizsgált személyek közül 15 fó a betegség primer ( 6 férfi és 9 nő), míg 13 fó a betegség szekunder formájában szenvedett (4 férfi és 9 nő). A panaszok hátterével összefüggő társ- és alapbetegségek az alábbiak voltak: 8 főnél pajzsmirigybetegség, 3 fơnél szisztémás sclerosis és 2 fơnél kézalagút-szindróma. A vizsgálatban való részvétel önkéntes és anonim volt, jutalomban a részvételért cserébe nem részesültek a betegek. A 2017. november-december közötti adatgyưjtést megelőzően megtörtént az etikai és intézményi engedélyek beszerzése. A kutatásra vonatkozó etikai engedély száma: RKEB/IKEB 48222017.

A munka első fázisában az interjúk teljes szövegét szó szerint rögzítettük. A szöveg mondatainak tartalmát a szövegben használt fogalmak gyakorisága és hasonlósága alapján kategorizáltuk. Így az interjúk teljes szövege strukturált tartalmi keretbe fókuszálva jelenhetett meg, azaz a szöveg nyelvi megjelenéséból kiemeltük a betegséget leíró és azzal összefüggő tartalmakat. Mindez lehetővé tette, hogy a betegek betegségükhöz való viszonyát és azzal kapcsolatos élményeiket rendszerezve megjelenítsük. A kérdésekre adott válaszok szövegéből így emelkedtek ki a tartalmi kategóriák.

\section{Eredmények}

A 12 kérdés által nyert adathalmaz összesített elemzése révén az életminőség nyolc - a betegség és a kapcsolódó életmódbeli változások által érintett - területe került azonosításra, illetve további résztémák rajzolódtak ki a fóbb területeken belül. A nyolc föterület az alábbi volt: (1) Tünetek élménye, (2) Funkcióromlás, (3) Kezelés és megelőzés, (4) Társas kapcsolatok, (5) Érzelmi és kognitív terheltség, (6) Munka, (7) Közlekedés és (8) Alvás. $\mathrm{Az}$ életminőség érintett fö- és részterületeinek részletesebb struktúrája az 1. táblázatban látható.

A Tünetek élménye terület olyan válaszokból alakult ki, amelyek a betegség fó fizikai tüneteiból állnak össze. Idetartozik a kéz és a láb, és ezeken a területeken is kifejezetten az ujjak színének változása (fehér/sárga; kék/ lila és vörös/rózsaszín); a végtagok lehúlése, fájdalma, zsibbadása, valamint általános sérülékenység (például tisztítószerekre) és hőmérsékletre vonatkozó érzékenység. Több beteg is beszámolt a kezek és a lábak dagadásáról, duzzadásáról: „mintha vizesek lennének a kezeim belülrôl’, illetve néhányan beszámoltak a kezek szárazságáról és hámlásáról is.

A Funkcióromlás terület azokat a kezek és a lábak használatát érintő nehézségeket jelöli, mint a különböző használati tárgyak fogására, szorítására való csökkent képesség, ami ügyetlenséggel, a tárgyak gyakori elejtésével jár: „könnyen elejtek dolgokat”. A betegek számára a kezeket érintő tünetek miatt a finommozgások kivitelezése nehézséggel jár, illetve jóval több időre van szükségük egy-egy feladat végrehajtására. A lábakkal kapcsolatos panaszok pedig gyakran járási nehézségeket okoznak: „bukdácsolok”, „könnyen megbotlok”.

A Kezelés és megelőzés terület azokat az intézkedéseket és kísérleteket foglalja magában, amelyeket a betegek a panaszaik enyhítése vagy megelőzése céljából végeznek. Ide a mozgatás, tornáztatás és dörzsölgetés tarozik, amelyek célja a hőmérséklet növelése és a vérkeringés fokozása. A betegek beszámoltak arról is, hogy próbálnak melegebben öltözködni: gyakran viselnek kesztyüt, vas- 
1. táblázat $\mid \mathrm{Az}$ interjúk tartalomelemzése során kialakult fớ- és résztémák struktúrája

\begin{tabular}{|c|c|}
\hline \multirow[t]{6}{*}{ 1. Tünetek élménye } & Fizikai változások \\
\hline & Hidegség érzése \\
\hline & Zsibbadás \\
\hline & Fájdalom \\
\hline & Hőmérséklet-érzékenység \\
\hline & Sérülékenység \\
\hline \multirow[t]{6}{*}{ 2. Funkcióromlás } & Merevség \\
\hline & Fogásproblémák \\
\hline & Elejtési tendenciák \\
\hline & Járási nehézségek \\
\hline & Időigényesség \\
\hline & Emelési nehézségek \\
\hline \multirow[t]{3}{*}{ 3. Kezelés és megelőzés } & Mozgatás \\
\hline & Öltözködés \\
\hline & Melegítés \\
\hline \multirow[t]{3}{*}{ 4. Társas kapcsolatok } & Érintés \\
\hline & Kellemetlen helyzetek \\
\hline & Elkerülő viselkedés \\
\hline \multirow[t]{7}{*}{ 5. Érzelmi és kognitív terheltség } & Jövő \\
\hline & Kinézet \\
\hline & Kontrollhiány \\
\hline & Oki bizonytalanság \\
\hline & Hidegérzékenység \\
\hline & Zaklatottság \\
\hline & Perseveratio \\
\hline 6. Munka & Korlátozottság \\
\hline 7. Közlekedés & Korlátozottság \\
\hline 8. Alvás & Zavartság \\
\hline
\end{tabular}

tagabb zoknit, ezekből néha egyszerre többet is: „kéthárom zoknit kell felvennem" a munkahelyen és otthon is: „otthon is kesztyüt hordok”. Kiemelték, hogy az őszi és a tavaszi időszakban már érezhetően sokkal több ruhát kell felvenniük, mint a többi embernek. Mindezeken túl folyamatosan próbálnak melegebb környezetet kialakítani a tartózkodási hely melegítésével vagy meleg tárgyakkal való érintkezéssel, például forró tea, zsebmelegítő vagy forró vizes fürdő.

A betegség szociális interakciókban való megjelenésére utaló válaszok a Társas kapcsolatok területében kerültek összefoglalásra. A kéz fizikai jellemzőinek változása gyakran nemcsak a beteg számára érzékelhető, hanem a beteggel kapcsolatba lépő személyek is észlelik a tünetek pregnáns jellege miatt: „csúnya lila, nem szép látvány”, „megijednek attól, abogyan a kezeim kinéznek”. Idesoroltuk még a kéz érintésének kellemetlenségét: „megérintem a férjem, és szól, hogy engedjem el, mert hideg (a kezem)”. A megváltozott igények konfliktusok forrásai is lehetnek: „nem értik, hogy miért problémázok annyit a bideg miatt", és kellemetlen helyzeteket okozhatnak: „mások mondják, hogy bogy néz $k i$ ”. Mindezek a betegekben elkerülő viselkedési reakciókat váltanak ki: „legszivesebben eldugnám”, „rejtegetni kell”, „inkább nem megyek társaságba”.

$\mathrm{Az}$ Érzelmi és kognitív terheltség terület olyan válaszokból alakult ki, amelyek a betegségre adott affektív és kognitív reakciókra vonatkoztak. Ide a jövővel kapcsolatos aggodalmak tartoznak: ,hova fog fajulni? Lehet, még kevésbé fogom tudni használni”, valamint a kezek csökkent esztétikai értékével kapcsolatos érzelmek, fóleg a szégyen: „szégyellem, mert olyan, mintha öregasszony lennék”, továbbá a kontrollvesztés érzése: „nem tudok védekezni” és a betegség okával kapcsolatos bizonytalanság: „megmagyarázhatatlan, hogy miért van”. Emellett a betegek számára a panaszok érzelmi zaklatottságot okoznak: „idegesit, depressziós érzés, mert nebéz vele együtt élni”, és a hideg is negatív érzelmeket vált ki: „allergiás vagyok a hidegre”. Ezeken túl a betegeknek gyakran kell az öltözködésen, az időjáráson és a szükséges megelőző intézkedéseken gondolkodni: „folyton figyelni kell rá, hogy mikor jön”.

Az utolsó három főterület a mindennapi élet olyan általános szféráit érinti, mint a Munka, az Alvás és a Közlekedés. A betegek számára a panaszok jelentős korlátozó tényezöt jelentenek a munkavégzésben: „néha annyira zsibbadnak a kezeim, hogy abba kell hagynom" és a közlekedésben: ,ha nagyon hideg van, akkor gyalog nem mehetek sehova"; illetve az alvást is megzavarják: „éjszaka anynyira zsibbad, hogy felébredek rá”.

Az életminőségek jellemző különböző területein a más-más nemú és életkorú betegek között nem találtunk jelentős eltérést. Az interjúk alapján nem fedeztünk fel különbséget a primer és a szekunder típusok között sem. Látva a kategóriarendszert ez részben érthető, hiszen a két típus nem különbözik a tüneti viselkedésében és az ahhoz társuló magatartásban, mivel a Raynaud-szindróma okozta alkalmazkodási nehézség és tüneti terhelés állt vizsgálatunk fókuszában.

\section{Megbeszélés}

Kutatásunk célja az volt, hogy kvalitatív módszerrel megvizsgáljuk a Raynaud-szindrómában szenvedőknél a panaszok okozta életminőség-romlást. Vizsgálatunk szerint a betegség a mindennapi élet csaknem összes területére rányomja bélyegét, s ezzel jól leírható életminőségromlást okoz. Más krónikus betegségekhez hasonlóan [32-34], a Raynaud-szindrómások számára fizikai, szociális, érzelmi és kognitív szinteken is tapasztalható a betegség megterhelő volta. Az interjúk tartalomelemzése során az életminőség érintettségét az alábbi nyolc főterület mentén értelmeztük: Tünetek élménye, Funkcióromlás, Kezelés és megelőzés, Társas kapcsolatok, Érzelmi és kognitív terheltség, Munka, Közlekedés, és Alvás. Ezek alapján megállapíthatjuk, hogy a betegség az életminősé- 
get jelentős alkalmazkodási teherrel járó tényezők mentén rontja.

A korábbi kutatási eredmények alapján a stressz fontos szerepet tölt be a Raynaud-szindrómában [2]. Ugyanakkor megállapíthatjuk, hogy a leírt életminőséget rontó tényezők további stresszorként hatnak. Olyan gyógyszerek még nem állnak rendelkezésre, amelyek jelentős mellékhatások nélkül hatékony kezelést jelenthetnének a betegek számára $[24,25]$. A betegség nagy terhet jelent a mindennapi élet során [26-28], amelyet jelen vizsgálatunk alátámasztott. Ezek a tényezők együttesen a betegek gyógyulási esélyeinek és életminőségének hosszú távú csökkenéséhez vezethetnek. Mindezek alapján úgy tûnik, hogy a szupportív életvezetési tanácsadás és a pszichoterápiás segítségnyújtás indokolt a Raynaud-szindrómában szenvedőknél. Ez különösen azokban az esetekben lehet fontos, ahol az alkalmazott kezelési módok súlyos mellékhatásokkal járnak/járnának; a panaszok száma a kezelés hatására nem csökken szignifikánsan; a stressz nyilvánvalóan kiváltó fakor; illetve az életminőségben jelentős romlás tapasztalható. A téma nyitott kérdéseinek megválaszolásához - például a stressz miért és hogyan kiváltó tényező; milyen kezelési mód (gyógyszeres és/vagy pszichoterápiás) a leghatékonyabb - további élettani és egészségpszichológiai kutatások szükségesek.

A nem, az életkor, illetve a primer vagy szekunder altípus esetén nem tudtunk olyan speciális mintázatokat találni, amelyek szempontjából az adott alcsoportok érdemben különböztek volna. Kvalitatív vizsgálatunk eredményei megfelelő alapot teremtenek egy Raynaudszindrómára specifikus kvantitatív életminőség-mérő kérdőív összeállításához. A specifikus elemeken túlmenően az általános életminőséget és releváns pszichológiai tényezőket - stressz, depresszió, szorongás - mérő skálák bevonásával a közeljövőben lehetővé válhat differenciált kvantitatív elemzés végzése nagyobb számú Raynaud-szindrómás beteg körében. A Raynaud-szindrómában szenvedók gyógyításában - mint ahogy az interjúk tapasztalatai is igazolják - nem tekinthetünk el az életminőséget rontó, vélhetően a betegség kialakulása során is megjelenő, de következményeikben is meghatározó stresszorok figyelembevételétől.

Anyagi támogatás: A munka a GINOP-2.3.2-15-201600062 azonosítószámú, „Életminőség fejlesztése KeletMagyarországon: Táplálkozás-, teljesítménybiológiai és biotechnológiai experimentális kutatások és eszközfejlesztések a humán megbetegedések megelőzésére és kezelésére" című projekt támogatásával történt.

Szerzôi munkamegosztás: F. B.: Az interjúk felvétele, a kézirat megszövegezése. B. A.: Részvétel a módszertani kialakításban, az eredmények értékelésében és a tanulmány végleges formájának kialakításában, javítás. Cs. Z.: Részvétel a háttérirodalom összegyưijtésében, szakértői részvétel az eredmények értékelésében, a tanulmány kiegészítése, szakértő lektorálás. A cikk végleges változatát mindhárom szerző elolvasta és jóváhagyta.

Érdekeltségek: A szerzőknek nincsenek érdekeltségeik.

\section{Irodalom}

[1] Takáts A, Garai I, Papp G, et al. Raynaud's syndrome, 2011. [Raynaud-szindróma, 2011.] Orv Hetil. 2012; 153: 403-409. [Hungarian]

[2] Wigley FM. Raynaud's phenomenon. N Engl J Med. 2002; 347: 1001-1008.

[3] Garner R, Kumari R, Lanyon P, et al. Prevalence, risk factors and associations of primary Raynaud's phenomenon: systematic review and meta-analysis of observational studies. BMJ Open 2015; 5: e006389.

[4] Lewis T. Experiments relating to the peripheral mechanism involved in spasmodic arrest of the circulation in the fingers, a variety of Raynaud's disease. Heart 1929; 15: 7-101.

[5] Bowling JC, Dowd PM. Raynaud's disease. Lancet 2003; 361: 2078-2080.

[6] Goundry B, Bell L, Langtree M, et al. Diagnosis and management of Raynaud's phenomenon. BMJ 2012; 344: 37-42.

[7] Block JA, Sequeira W. Raynaud's phenomenon. Lancet 2001; 357: 2042-2048.

[8] Maverakis E, Patel F, Kronenberg DG, et al. International consensus criteria for the diagnosis of Raynaud's phenomenon. J Autoimmun. 2014; 48-49: 60-65.

[9] Maricq HR, Carpentier PH, Weinrich MC, et al. Geographic variation in the prevalence of Raynaud's phenomenon: a 5 region comparison. J Rheumatol. 1997; 24: 879-889.

[10] Csiki Z, Gál I, Sebesi J, et al. Raynaud syndrome and eradication of Helicobacter pylori. [Raynaud-szindróma és Helicobacter pylori-eradikáció.] Orv Hetil. 2000; 141: 2827-2829. [Hungarian]

[11] Czuriga I, Édes I. Beta-adrenergic receptor blockers in clinical practice. [Béta-adrenerg-receptor-blokkolók a klinikai gyakorlatban.] Orv Hetil. 2004; 145: 1951-1960. [Hungarian]

[12] Kiss E, Dankó K, Sütő G, et al. Shared and distinctive characteristics of systemic autoimmune disorders. [A szisztémás autoimmun betegségek közös és eltérő sajátosságai.] Orv Hetil. 2007; 148(Suppl 1): 44-51. [Hungarian]

[13] Bolster M, Silver R. Clinical features of systemic sclerosis. In: Hochberg M, Silman A, Smolen J, et al. (eds.) Rheumatology, Vol. 2, 5th edn. Elsevier, Philadelphia, PA, 2011; pp. 13731385 .

[14] Bodolay E, Szegedi G. Undifferentiated connective tissue disease. [Nem differenciált collagenosis 2009-ben.] Orv Hetil. 2009; 150: 867-872. [Hungarian]

[15] Kiss E, Tarr T, Soltész P, et al. Critical situations in systemic lupus erythematosus. [Krízisállapotok szisztémás lupus erythematosusban.] Orv Hetil. 2006; 147: 2469-2473. [Hungarian]

[16] Bodolay E, Szegedi G. Undifferentiated connective tissue disease: the clinical and serological profile of 578 patients followed for five years: disease course, prognosis and therapy. [Nem differenciált collagenosisban szenvedő betegek ötéves követésével nyert megfigyelések: 578 beteg klinikai és immunszerológiai sajátossága, kórlefolyás, terápia.] Orv Hetil. 2002; 143: 229-233. [Hungarian]

[17] Csiki Z, Gál I, Szücs G, et al. Comments of Raynaud's syndrome based upon laser-Doppler studies. [Észrevételek a Raynaud-szindrómáról lézer Doppler-mérésekkel szerzett tapasztalatok alapján.] Orv Hetil. 1999; 140: 2285-2288. [Hungarian]

[18] Pope JE. The diagnosis and treatment of Raynaud's phenomenon. Drugs 2007; 67: 517-525. 
[19] Suter LG, Murabito JM, Felson DT, et al. The incidence and natural history of Raynaud's phenomenon in the community. Arthritis Rheum. 2005; 52: 1259-1263.

[20] Kákosy T, Németh L, Kiss G, et al. Clinical features of the handarm vibration syndrome of the miners. [A bányászok kéz-kar vibrációs szindrómájának klinikai képe.] Orv Hetil. 2006; 147: 833-839. [Hungarian]

[21] Kákosy T, Németh L, Hazay B, et al. Hand-arm vibration syndrome on caisson-miners. [Kéz-kar vibrációs szindróma keszonvájárokon.] Orv Hetil. 1997; 138: 1743-1746. [Hungarian]

[22] Csiki Z, Garai I, Shemirani AH, et al. The effect of metoprolol alone and combined metoprolol-felodipin on the digital microcirculation of patients with primary Raynaud's syndrome. Microvasc Res. 2011; 82: 84-87.

[23] Thompson AE, Pope JE. Calcium channel blockers for primary Raynaud's phenomenon: a meta-analysis. Rheumatology 2005; 44: 145-150.

[24] García-Carrasco M, Jiménez-Hernández M, Escárcega RO, et al. Treatment of Raynaud's phenomenon. Autoimmun Rev. 2008; 8: 62-68.

[25] Wigley F, Wise R, Haythornthwaite J, et al. Comparison of sustained-release nifedipine and temperature biofeedback for treatment of primary Raynaud phenomenon - Results from a randomized clinical trial with 1-year follow-up. Arch Intern Med. 2000; 160: 1101-1108

[26] Bassel M, Hudson M, Taillefer SS, et al. Frequency and impact of symptoms experienced by patients with systemic sclerosis: results from a Canadian National Survey. Rheumatology 2010; 50: 762-767.

[27] Merkel PA, Herlyn K, Martin RW, et al. Measuring disease activity and functional status in patients with scleroderma and Raynaud's phenomenon. Arthritis Rheum. 2002; 46: 24102420 .
[28] De Angelis R, Salaffi F, Grassi W. Health-related quality of life in primary Raynaud phenomenon. J Clin Rheumatol. 2008; 14: 206-210.

[29] Hughes M, Snapir A, Wilkinson J, et al. Prediction and impact of attacks of Raynaud's phenomenon, as judged by patient perception. Rheumatology 2015; 54: 1443-1447.

[30] Czimbalmos Á, Nagy Zs, Varga Z, et al. Patient satisfaction study with SF-36 questionnaire: measuring Hungarian normative data. [Páciens megelégedettségi vizsgálat SF-36 kérdő́ivvel, a magyarországi normálértékek meghatározása.] Népegészségügy 1999; 80(1): 4-19. [Hungarian]

[31] Paulik E, Belec B, Molnár R, et al. Applicability of the brief version of the World Health Organization's quality of life questionnaire in Hungary. [Az Egészségügyi Világszervezet rövidített életminőség kérdőívének hazai alkalmazhatóságáról.] Orv Hetil. 2007; 148: 155-160. [Hungarian]

[32] Mitchell AJ, Benito-León J, González JM, et al. Quality of life and its assessment in multiple sclerosis: integrating physical and psychological components of wellbeing. Lancet Neurol. 2005; 4: 556-566.

[33] McElhone K, Abbott J, Shelmerdine J, et al. Development and validation of a disease-specific health-related quality of life measure, the LupusQoL, for adults with systemic lupus erythematosus. Arthritis Care Res. 2007; 57: 972-979.

[34] Ward MM. Health-related quality of life in ankylosing spondylitis: a survey of 175 patients. Arthritis Care Res. 1999; 12: 247255 .

(Fábián Balázs, Debrecen, Pf. 45,4032 e-mail: fabian.balazs@sph.unideb.hu)

\title{
ÁLLÁSAJÁNLAT
}

\section{a Szombathelyi Országos Büntetés-végrehajtási Intézet felvételt hirdet}

- Főállású, vagy közremüködői szerződéssel (heti meghatározott óraszámban) szakorvosi beosztás betöltésére - háziorvos vagy belgyógyász szakorvosi végzettséggel rendelkező - magyar állampolgár, egészségügyileg alkalmas, kifogástalan életvitelü, büntetlen előéletü, érvényes kamarai tagsággal és müködési nyilvántartással rendelkező személyek részére.

- Szakápolói beosztás betöltésére hivatásos, illetve közalkalmazotti jogviszonyban - ápoló OKJ 54/55 végzettséggel rendelkező - magyar állampolgár, egészségügyileg alkalmas, kifogástalan életvitelü, büntetlen előéletü, érvényes működési nyilvántartással rendelkező személyek részére.

\section{A szakmai önéletrajzokat az alábbi címre várjuk:}

\author{
Szombathelyi Országos Büntetés-végrehajtási Intézet \\ 9700 Szombathely, Söptei út \\ e-mail: szombathely.uk@bv.gov.hu
}

